Smith test ${ }^{2}$ for peptides but was negative to ninhydrin. However, when the inhibitor concentrate was hydrolysed with $2 \mathrm{~N}$ hydrochloric acid at $100^{\circ} \mathrm{C}$. for $20 \mathrm{hr}$. and chromatographed similarly, 4-5 nin. hydrin-positive spots were obtained, depending upon the source from which the inhibitor had been extracted.

These properties, together with the fact that the inhibitor is formed on autoclaving lactose with a number of proteins, tryptone and amino-acids, indicate that it is peptide in nature.

Further studies on the exact composition of this inhibitor and its mode of action are in progress and will be reported elsewhere.

We are indebted to Dr. L. D. Wright, Cornell University, for the culture of $L$. bulgaricus 09 and to the Madras State Research Committee for financial assistance during the course of this study.

$$
\begin{aligned}
& \text { L. VISwanathan } \\
& \text { P. S. SARMA }
\end{aligned}
$$

University Biochemical Laboratory, Madras 25.

${ }^{1}$ Wright, L. D., Valentik, K. A., Spicer, D. S., Huff, J. W., and Skeggs, H. R., Proc. Soc. Exp. Biol. Med., 75, 293 (1950). 2 Rydon, H. N., and Smith. P. G. W., Nature, 162, 922 (1952).

\section{Pigments and Pterins in the Skin of the Green Mamba, Dendroaspis viridis}

Ir has previously been reported that the skins of the green snakes Philothamnus semivariegatus and Dispholidus typus contain riboflavin, isoxanthopterin and 2-amino-4-hydroxpteridine-6-carboxylic acid 1,2. $D$. typus also contains 2-amino-4-hydroxypteridin $\theta^{2}$ and an unknown yellow pigment ${ }^{1}$.

After this investigation had been completed, a single male specimen of the green mamba, Dendroaspis viridis, became available to us. The enterior and middle portions were leaf green, and the posterior portion dull yellow.

The animal was skinned and the skin cut into the green and yellow portions.

The yellow skin was extracted with $50 \mathrm{ml}$. portions of boiling 80 per cent aqueous ethanol, in the dark, until the extract was colourless. The combined extracts were evaporated to dryness, the residue dissolved in $50 \mathrm{ml}$. of $\mathrm{N} / 4$ aqueous ammonia and the solution filtered from insoluble material. Analysis of this solution by paper chromatography showed the presence of a yellow non-fluorescent pigment; and, on viewing in $365 \mathrm{~m} \mu$ light, an additional yellow fluorescent substance, a purple fluorescent substance, a bright blue fluorescent substance and a blue fluorescent substance.

The yellow fluorescent substance was identified as riboflavin by its similar behaviour to an authentic sample in three solvent systems; pyridine/propanol/ water (3:1:1 by vol.); tert-butanol/pyridine/water (50: $15: 35$ by vol.) ; and tert-butanol/pyridine/water ( $60: 15: 25$ by vol.).

The purple fluorescent substance was identified as isoxanthopterin, the bright blue fluorescent substance as 2-amino-4-hydroxypteridine-6-carboxylic acid, and the blue fluorescent substance as 2-amino-4-hydroxpteridine. This was done by comparing their behaviour with that of authentic samples in the three previous solvent systems and in butanol/acetic acid/ water (4:1:5 by vol.); 5 per cent aqueous acetic acid (by vol.); and 3 per cent aqueous ammonium chloride.

The yellow non-fluorescent substance could not be identified. Its chromatographic behaviour in butanol/ acetic acid/water (4: $1: 5$ by vol.) was similar to that of the unknown yellow pigment in $D$. typus ${ }^{1}$.

The green portion of the skin was extracted with $50 \mathrm{ml}$. portions of boiling 80 per cent aqueous ethanol until the extract was colourless. The extracts were combined, and the presence of riboflavin and isoxanthopterin was shown by paper chromatography, as before. No attempt was made to identify 2 -amino4-hydroxypteridine-6-carboxylic acid nor 2-amino-4hydroxypteridine in the ethanolic extract. The yellow non-fluorescent substance was present.

I am grateful to Mr. A. H. Booth of the Zoology Department of this College for supplying the specimen of D. viridis ; and to the Chemical Society for a grant in aid of this investigation.

\section{J. A. Brarr}

University College of Ghana, Achimota, Ghana, West Africa.

1 Blair, J. A., and Graham, J., Biochem. J., 56, 286 (1954).

2 Blair, J. A., and Graham, J., Chem. and Ind., 1158 (1955).

\section{Onset and Cessation of Hibernation under Constant Temperature and Light in the Golden-mantled Ground Squirrel (Citellus lateralis)}

Towards the end of the summer of 1955 we received, through the kindness of Dr. J. E. Moore (University of Alberta), a number of golden mantled ground squirrels (Citellus lateralis). These animals had been trapped during August-September in the Turner Valley, Alberta, and were shipped to Toronto by express. Our stock was further replenished in the same manner during the summer of 1956.

One of the experiments we have undertaken involved placing a squirrel in a cold room with a mean temperature of about $35^{\circ} \mathrm{F}$. (min., $30^{\circ} \mathrm{F}$.; max., $42^{\circ}$ F.) and leaving it there indefinitely. At the present time (July 1957) one animal has been there for nearly two years, and during this time has had ample bedding, food and water ad lib., and has been subject to an artificial $12-\mathrm{hr}$. day throughout. Or to put it another way, the animal has been removed from all known seasonal fluctuations in temperature, light and availability of food. Notwithstanding this, it seems remarkable that the squirrel has hibernated only at 'the right time of year', that is, autumn-winter (October-May) and has been active only at the 'right time of year', that is, springsummer (June-September).

Thus far only one animal has been under these constant conditions for this length of time. However, from data on eight other animals ( 3 males, 5 females) which have been in our possession for the same length of time, but which have been subject to varying conditions of temperature, light, food and access to exercise wheels, all show a tendency to hibernate over the winter months and to be active in the summer months regardless of the temperature and the length of the artificial day. During June-September denial of food, which is accompanjed by a large drop in weight, will after several days force the animal to hibernate ; but it cannot survive this for long, whereas 